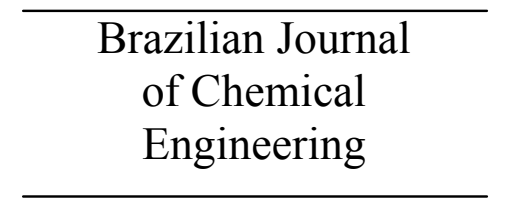

ISSN 0104-6632

Printed in Brazil

www.abeq.org.br/bjche

Vol. 29, No. 01, pp. 31 - 38, January - March, 2012

\title{
SUGAR CANE BAGASSE PREHYDROLYSIS USING HOT WATER
}

\author{
D. Abril ${ }^{1 *}$, M. Medina ${ }^{2}$ and A. Abril ${ }^{2}$ \\ ${ }^{1}$ Facultad de Ciencias Básicas, Universidad Católica del Maule, Phone: + 5671 203402, Fax: + 5671413654 , \\ Avenida San Miguel 3605, Talca, Chile. \\ E-mail: dabril@ucm.cl \\ ${ }^{2}$ Dirección de Química. Instituto Cubano de Investigaciones de los Derivados de la Caña de Azúcar, \\ ICIDCA, Vía Blanca y Carr. Central, Habana, Cuba.
}

(Submitted: September 3, 2010 ; Revised: August 24, 2011 ; Accepted: September 16, 2011)

\begin{abstract}
Results are presented on the hot water prehydrolysis of sugar cane bagasse for obtaining ethanol by fermentation. The experimental study consisted of the determination of the effect of temperature and time of prehydrolysis on the extraction of hemicelluloses, with the objective of selecting the best operating conditions that lead to increased yield of extraction with a low formation of inhibitors. The study, carried out in a pilot plant scale rotational digester, using a $3^{2}$ experimental design at temperatures of $150-190^{\circ} \mathrm{C}$ and times of 60-90 min, showed that it is possible to perform the hot water prehydrolysis process between $180-190^{\circ} \mathrm{C}$ in times of $60-82 \mathrm{~min}$, yielding concentrations of xylose $\geq 35 \mathrm{~g} / \mathrm{L}$, furfural $\leq 2.5 \mathrm{~g} / \mathrm{L}$, phenols from soluble lignin $\leq 1.5 \mathrm{~g} / \mathrm{L}$, and concentrations $\leq 3.0 \mathrm{~g} / \mathrm{L}$ of hemicelluloses in the cellolignin residue. These parameters of temperature and prehydrolysis time could be used for the study of the later hydrolysis and fermentation stages of ethanol production from sugar cane bagasse.

Keywords: Ethanol cellulosic; Alcoholic fermentation; Water prehydrolysis.
\end{abstract}

\section{INTRODUCTION}

The conversion of lignocellulosic materials to ethanol by biochemical means consists of the following stages (Lynd et al., 2002):

1. Pretreatment, to make the material more susceptible and accessible for the next stages.

2. Prehydrolysis, that releases and extracts the hemicelluloses contained in the material.

3. Hydrolysis, to transform the cellulose and hemicelluloses to hexoses and pentoses.

4. Fermentation of the hexoses and pentoses to ethanol.

5. Separation and concentration of ethanol.

The two critical stages in the technical-economic efficiency of the process of obtaining ethanol from lignocellulosic biomass are pretreatment and prehydrolysis. They can be decisive for the feasibility of the process of biochemical conversion of the sugars to ethanol (Zhui et al., 2008; Mabee et al. 2006).

The composition of lignocellulosic materials is complex and they have a difficult structure to penetrate and attack with chemical agents, requiring a pretreatment in order to "break" this structure and facilitate the later processes (Hahn-Hagerdal et al., 2006).

None of the proposed pretreatment-prehydrolysis methods can be applied in generic form to the different raw materials (Claassen et al., 1999).

The selection of an efficient pretreatmentprehydrolysis process, according to the characteristics of the lignocellulosic material, results in conversion rates of cellulose hydrolysis to glucose of more than $90 \%(\mathrm{w} / \mathrm{w})$ of the theoretical yield (Wyman et al., 2005)

Steam explosion is the method most employed for the prehydrolysis of lignocellulosic materials. In this

*To whom correspondence should be addressed 
method, the biomass undergoes treatment with vapor at high temperature and pressure and later on a quick decompression is carried out, which causes the explosion of the cellular tissue and the separation of its components to a certain extent that facilitates the later hydrolysis (Sun and Cheng, 2002). The addition of $\mathrm{H}_{2} \mathrm{SO}_{4}, \mathrm{SO}_{2}$, and $\mathrm{CO}_{2}$ improves the later hydrolysis (Morjanoff and Gray, 1987). Its main disadvantage is the formation of inhibitors of the fermentation (Klinke et al., 2004).

Another prehydrolysis is the Ammonia fiber explosion AFEX. In this process, the material undergoes the attack of liquid ammonia at high temperature and pressure and later a quick decompression is carried out. This process does not generate inhibitors of the fermentation (Mes-Hartree et al., 1988).

Ozone can also be used for the prehydrolysis of lignocellulosic materials. The prehydrolysis with ozone has the advantage of being carried out at ambient temperature and atmospheric pressure and does not generate inhibitors (Vidal and Molinier, 1988).

Dilute acids are used in a satisfactory way for prehydrolysis. Dilute sulfuric acid allows one to achieve high reaction velocities and improves the hydrolysis of cellulose in a significant way (Wyman et al., 2005).

In general, two prehydrolysis processes are used with diluted acids. High temperatures $\left(>160^{\circ} \mathrm{C}\right)$ continuous processes with a low content of solids (5-10\%) (Kádár et al., 2007) and low temperatures, $\left(<160^{\circ} \mathrm{C}\right)$ in a discontinuous mode with high contents of solids (10-40\%) (Esteghlalian et al., 1997). Studies of Liu and Wyman (2003) showed that an increment of the rate of flow improves the extraction of hemicelluloses and lignin in the prehydrolysis with hot water at pressure or very diluted sulfuric acid and high temperatures.

In the case of biological pretreatment, white, brown and other fungus have been used for the degradation of lignin and hemicelluloses in lignocellulosic materials (Jacobsen and Wyman, 2002).

The biodegradation of lignin can be catalyzed with the enzyme peroxidase in the presence of $\mathrm{H}_{2} \mathrm{O}_{2}$ (Azzam, 1989). The prehydrolysis of sugar cane bagasse with $\mathrm{H}_{2} \mathrm{O}_{2}$ (Bjerre, 1996; Brienzo et al., 2009) and the Mild Alkaline/Oxidative process (Cheng et al., 2008) significantly improves its susceptibility to enzymatic hydrolysis (Bjerre, 1996).

Several studies of sugar cane bagasse hydrolysis with $\mathrm{H}_{3} \mathrm{PO}_{4}, \mathrm{HNO}_{3}$ and other dilute acids are presented (Gámez et al., 2004, 2006; RodríguezChong et al., 2004; Lavarack et al., 2002; Martín, 2002; Laopaiboon et al., 2010 ; Canilha et al., 2008).
At the present time, the biggest contribution to the cost of the process is the cost of the enzymes, but with the new developments that are being occurring in this field, the cost of the enzymes will diminish significantly. In 2012, the most expensive stage will be the pretreatment- prehydrolysis (Zhui et al., 2002).

This report presents the results of a study of the stage of hot water prehydrolysis of sugar cane bagasse for obtaining ethanol by the biochemical way. At temperatures over $150^{\circ} \mathrm{C}$, water acts as a weak acid which, together with the formation of organic acids during the prehydrolysis, makes this process in effect a dilute acid prehydrolysis process.

The objective of the study of the water prehydrolysis process of sugar cane bagasse was to find the optimum values of temperature and time in the range studied of these parameters to obtain the highest extraction of hemicelluloses (xylose) into the liquid phase ( $\geq 35 \mathrm{~g} / \mathrm{L})$, with the minimum content of furfural and hydroxymethylfurfural $(\leq 2.5 \mathrm{~g} / \mathrm{L})$ and lignin (as phenolic compounds $\leq 1.5 \mathrm{~g} / \mathrm{L}$ ) and a maximum extraction of hemicelluloses $(\leq 3 \%$ in the cellolignin solid residue).

\section{MATERIALS AND METHODS}

Integral sugar cane bagasse, bulk stored in an experimental pile one meter high with 3 months of age from the Sugar Mill "Manuel Fajardo" in Habana Province, Cuba, was used in the experiments. Representative samples of one kilogram were taken at different heights. The chemical composition (cellulose, pentosans, lignin, extractives and ash) was determined by the TAPPI (Technical Association of Pulp and Paper Industries) Testing Procedures in all cases (TAPPI, 1988).

\section{Prehydrolysis Process}

The bagasse water prehydrolysis study was carried out in an $18 \mathrm{~L}$ stainless steel rotational digester with electrical heating and temperature control up to $200^{\circ} \mathrm{C}$.

The water prehydrolysis experiments were performed following a $3^{2}$ factorial experimental design in order to study the effect of temperature and time on the composition of the prehydrolysis liquor (xylose, furfural and hydroxymethylfurfural, phenolic compounds from lignin extraction and glucose from cellulose hydrolysis) and the content of hemicelluloses in the cellolignin solid residue. The levels of the factors were chosen taking into account previous results (Hernández et al., 2008). 
The hydromodule was fixed at 6, which represents the relationship in weight between the water solution and the solid phase (dry bagasse). The bagasse has $68 \%$ humidity, which has to be taken into consideration for the calculation of the amount of water to be added to the digester to fix the hydromodule.

The sugar cane bagasse (integral, $28 \%$ pith) was added to the rotary digester and the calculated quantity of tap water added to achieve a final hydromodule of 6 . The final volume of the digester was $10 \mathrm{~L}$ and the concentration of bagasse $200.0 \pm 0.4 \mathrm{~g} / \mathrm{L}$.

The temperature elevation time (to get to $150-190^{\circ} \mathrm{C}$ ) was $20 \mathrm{~min}$ (not considered in the 60,75 or $90 \mathrm{~min}$ of prehydrolysis time). At the end of the prehydrolysis, the digester was allowed to cool at room temperature

The content of the digester (cellolignin) was filtered through a 200 mesh wire sieve in order to separate the solid phase, which was washed with 5 portions of $200 \mathrm{ml}$ of water and dried at $105^{\circ} \mathrm{C}$ until constant weight. The liquid phase (prehydrolysis liquor and wash waters) is a greenish yellow liquid rich in xylose and other sugars and organic acids like acetic, phenolic compounds (lignin derivatives) and furfural.

\section{Analytical Methods}

\section{Xylose and Glucose (Cheng et al. 2008)}

The liquid samples were analyzed by HPLC, equipped with RI detectors. Glucose and xylose were analyzed using the refractive index detector and an Aminex HPX-87 $\mathrm{H}$ column at $65^{\circ} \mathrm{C}$ with $5 \mathrm{mM}$

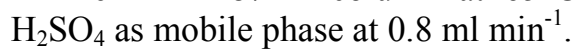

\section{Furfural, Hydroxymethylfurfural and Soluble Phenolic Compounds (Soluble Lignin) (Martínez et al. 2000).}

The samples of the prehydrolysis liquor were neutralized and filtered. The concentration of a mixture of furfural and hydroxymethylfurfural was determinated by UV spectroscopy with a UNICAM 8700 spectrometer (Pye Unicam, England) at $276 \mathrm{~nm}$. Soluble phenolic compounds formed from lignin were determined at $280 \mathrm{~nm}$.

\section{Hemicelluloses in Cellolignin}

The TAPPI official method T223om-82, based on the conversion of pentoses hydrolysed from hemicelluloses in furfural by $\mathrm{HCl}$, was used. In the case of sugar cane bagasse, because almost all the hemicelluloses are constituted by pentoses, this value is usually taken as the hemicelluloses content.

\section{Statistics}

Each data point reported is an average of five replicate tests. The $95 \%$ confidence interval of the mean value was calculated by the expression $\Delta=\mathrm{S}_{\mathrm{x}} \mathrm{t}_{(0.975)} / \mathrm{n}^{1 / 2}$, where $\Delta=$ confidence interval for the sample mean $( \pm), \quad \mathrm{Sx}=$ sample standard deviation, $\mathrm{t}=$ Student's $\mathrm{t}$ distribution with $\mathrm{n}-1$ degrees of freedom and $n=$ number of samples/tests.

\section{RESULTS AND DISCUSSION}

The chemical composition of integral sugar cane bagasse is shown in Table 1. The contents of cellulose, pentosans, and lignin are in the range reported in the literature. (Gálvez et al. 2000 ; Triana et al. 2008).

The results of experimental design are presented in Table 2. There is an increment in the concentration of xylose extracted from the hemicelluloses fraction of the material with the increment of temperature and time in the range studied. The main component of sugar cane hemicelluloses is xylose, although other monosacharides like arabinose, galactose, and others are present (Laser et al., 2002; Ferreira-Leitao et al., 2010). The effects of temperature and hydrolysis time on the concentration of xylose are presented in Figure 1. Concentrations of xylose between 24 and 42 $\mathrm{g} / \mathrm{L}$ are achieved under the conditions studied. Taking into account that the concentration of xylose in bagasse is $25.9 \%$ (considering that all the pentoses are xylose) (Table 1) and the concentration of bagasse in the prehydrolysis liquor is $200 \mathrm{~g} / \mathrm{L}$, the maximum concentration of xylose that could be achieved is $51.8 \mathrm{~g} / \mathrm{L}$. The results in Table 2 shows that a xylose extraction yield (24.5-42.5 g/L) between 46 and 81\% was achieved. Other authors (Gámez et al., 2004, 2006), using $4 \% \mathrm{H}_{3} \mathrm{PO}_{4}$ and $300 \mathrm{~min}$ at $122^{\circ} \mathrm{C}$ in the prehydrolysis of sugar cane bagasse reported obtaining $17.6 \mathrm{~g}$ of xylose/L; $2.6 \mathrm{~g}$ of arabinose/L; $3.0 \mathrm{~g}$ of glucose $/ \mathrm{L}$ and $1.2 \mathrm{~g}$ furfural/L. RodríguezChong et al. (2004) performed the hydrolysis with $6 \% \mathrm{HNO}_{3}$ and $9.3 \mathrm{~min}$ at $122^{\circ} \mathrm{C}$. Using these conditions, $18.6 \mathrm{~g}$ xylose $/ 1 ; 2.04 \mathrm{~g}$ arabinose $/ 1 ; 2.87 \mathrm{~g}$ glucose $/ \mathrm{L} ; 0.9 \mathrm{~g}$ acetic acid/L and $1.32 \mathrm{~g}$ furfural/L were obtained. In these two cases, the prehydrolysis were performed at lower temperatures, which explains the low extraction of xylose in spite of the relatively high concentration of acid. 
Table 1: Composition of integral sugar cane bagasse

\begin{tabular}{|l|c|l|}
\hline \multicolumn{1}{|c|}{ Component } & $\begin{array}{c}\text { Composition \% } \\
(\mathbf{w} / \mathbf{w})\end{array}$ & \multicolumn{1}{c|}{$\begin{array}{c}\text { Analytical Method } \\
\text { TAPPI }\end{array}$} \\
\hline Cellulose & $46.4 \pm 0,2$ & Cross and Bevan T17m-70 \\
Pentosans (Hemicelluloses) & $25.9 \pm 0,4$ & T223om-82 \\
Lignin & $23.6 \pm 0,4$ & Lignin acid insoluble in wood T222 \\
Extractives & $2.4 \pm 0,1$ & Extractive-freewood T12 \\
Ash & $3.7 \pm 0,3$ & Ash content T211 $\left(575^{\circ} \mathrm{C}\right)$ \\
\hline
\end{tabular}

Table 2: Results of experimental design

\begin{tabular}{|c|c|c|c|c|c|c|c|}
\hline Run & $\begin{array}{c}\text { Temp. } \\
\mathbf{( \mathbf { }} \mathbf{C})\end{array}$ & $\begin{array}{c}\text { Time } \\
(\mathbf{m i n})\end{array}$ & $\begin{array}{c}\text { Xylose } \\
\mathbf{( g / L )}\end{array}$ & $\begin{array}{c}\text { Furfural(1) } \\
\mathbf{( g / \mathbf { L } )}\end{array}$ & $\begin{array}{c}\text { Phenols (2) } \\
\mathbf{( g / \mathbf { L } )}\end{array}$ & $\begin{array}{c}\text { Glucose } \\
\mathbf{( g / \mathbf { L } )}\end{array}$ & $\begin{array}{c}\text { Hemicelluloses in } \\
\text { cellolignin } \mathbf{( \% )}\end{array}$ \\
\hline 1 & 150 & 60 & $24.5 \pm 0.1$ & $1.4 \pm 0,1$ & $0.30 \pm 0,03$ & $2.6 \pm 0,2$ & $5.1 \pm 0,3$ \\
2 & 170 & 60 & $32.4 \pm 0,3$ & $2.1 \pm 0,2$ & $0.82 \pm 0,01$ & $3.4 \pm 0,3$ & $3.6 \pm 0,3$ \\
3 & 190 & 60 & $35.4 \pm 0,3$ & $2.5 \pm 0,2$ & $1.20 \pm 0,04$ & $4.3 \pm 0,3$ & $2.3 \pm 0.1$ \\
4 & 150 & 75 & $28.6 \pm 0,2$ & $1.7 \pm 0,1$ & $0.51 \pm 0,04$ & $2.9 \pm 0,1$ & $4.3 \pm 0,4$ \\
5 & 170 & 75 & $34.3 \pm 0,3$ & $2.4 \pm 0,3$ & $1.12 \pm 0,03$ & $3.7 \pm 0,1$ & $3.3 \pm 0,2$ \\
6 & 190 & 75 & $37.5 \pm 0,4$ & $2.9 \pm 0,2$ & $1.53 \pm 0,03$ & $4.6 \pm 0,4$ & $2.5 \pm 0,1$ \\
7 & 150 & 90 & $30.9 \pm 0,3$ & $1.6 \pm 0,1$ & $0.73 \pm 0,04$ & $3.3 \pm 0,2$ & $3.9 \pm 0,3$ \\
8 & 170 & 90 & $39.2 \pm 0,2$ & $2.4 \pm 0,2$ & $1.31 \pm 0,01$ & $4.1 \pm 0,3$ & $2.9 \pm 0,1$ \\
9 & 190 & 90 & $42.5 \pm 0,3$ & $3.7 \pm 0,3$ & $2.04 \pm 0,04$ & $4.8 \pm 0,4$ & $2.1 \pm 0,3$ \\
\hline
\end{tabular}

(1) Furfural and Hydroxymethylfurfural (2) Soluble lignin

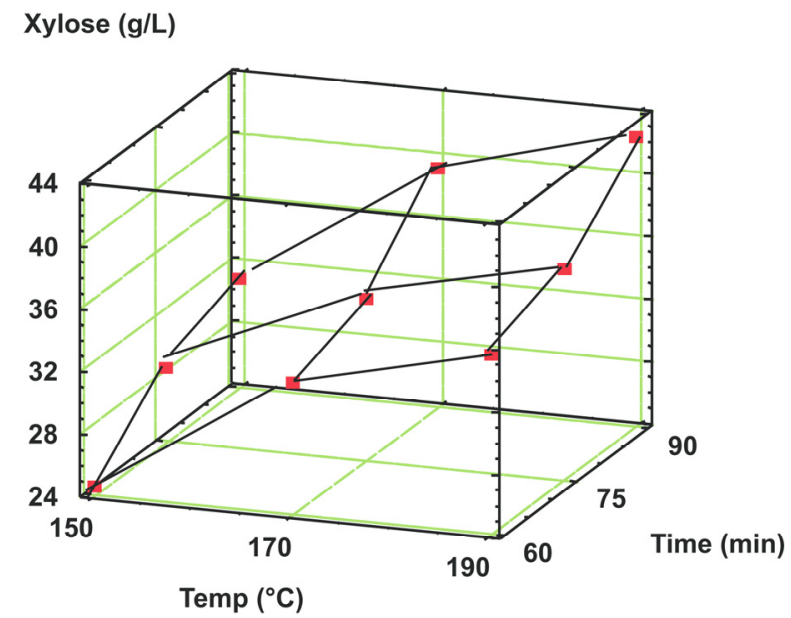

Figure 1: Xylose concentration in the prehydrolysis liquor.

Comparison of these results with those obtained using water prehydrolysis at higher temperatures $\left(150-190^{\circ} \mathrm{C}\right)$, in which high concentrations of xylose are achieved, demonstrated that the effect of the temperature is more important for the efficiency of extraction and hydrolysis of xylose.

Experimental trials of the dilute acid hydrolysis of bagasse hemicelluloses to produce xylose, arabinose, glucose, acid-soluble lignin (ASL) and furfural (Lavarack et al. 2002) were performed at $80-200^{\circ} \mathrm{C}$, hydromodules of 1:5-1:20, concentration of hydrochloric or sulfuric acid $0.25-8 \mathrm{wt} \%$ of the liquid and reaction times of 10-2000 min; yields of up to $220 \mathrm{mg}$ xylose/g solid were achieved, which represents about $80 \%$ of the theoretical xylose available from the bagasse.

Furfural and hydroxymethylfurfural (inhibitors of fermentation) are formed to some extent during the process because of the dehydration reaction of xylose and other hexoses. Concentrations are in the range of $1.4-3.7 \mathrm{~g} / \mathrm{L}$ and increase with temperature and hydrolysis time (Table 2). Concentrations of furfural and hydroxymethylfurfural lower than $2.5 \mathrm{~g} / \mathrm{L}$ are obtained and considered acceptable by 
different authors, because they can be easily removed by several methods (Martín, 2002; Vargas and Pereira, 2010; Balat et al., 2008; Lloyd and Wyman, 2003).

Soluble lignin and other phenol type compounds are also inhibitors of the fermentation process and some quantities of lignin are solubilized during the prehydrolysis. In the present study, concentrations between 1.20 and $2.04 \mathrm{~g} / \mathrm{L}$ were obtained, which represent $2.5-4.3 \%$ of the lignin present in bagasse (calculated from Table 1), results in accordance with others reported in literature (Martin, 2002 ; Neureiter et al., 2002; Robelo et al., 2009).

Because of this fact, it is very important to keep a compromise between the temperature and time of the hydrolysis in order to obtain the maximum of xylose extraction with the minimum formation of furfural, hydroxymethylfurfural and phenol derivatives from lignin, which are inhibitors of the fermentation process.

Keeping furfural and hydroxymethylfurfural at concentrations under $2.5 \mathrm{~g} / \mathrm{L}$ is not expected to be a problem, because at temperatures above $180^{\circ} \mathrm{C}$ they will be almost completely eliminated by evaporation during the degasification step of the reactor. Phenol derivatives from soluble lignin are also fermentation inhibitors and their concentration should be keeping lower than $1.5 \mathrm{~g} / \mathrm{L}$ in the prehydrolysis liquor. In the later stages of the prehydrolysis liquor purification process: neutralization, decantation, ion exchange, among others, the furfural, phenols and other impurities will decrease progressively to acceptable levels.

During the prehydrolysis step, some quantity of cellulose (mainly amorphous and of low molecular weight) is hydrolyzed to glucose. Table 2 shows the concentration of glucose in the prehydrolysis liquor. The concentration increases with the temperature and prehydrolysis time. The presence of glucose in the liquor does not affect the forward fermentation process hydrolyzes the cellulose to glucose. The hemicelluloses that remains in the cellolignin after the prehydrolysis are presented in Table 2. Concentrations lower than $3 \%$ will be considered to be good results for the hemicelluloses extraction during the prehydrolysis process.

The results of Table 2 were processed by a multiple regression program (Statgraph 5 Pro) and the regression equations are presented in Table 3 . All the equations show correlations coefficients higher than $90 \%$. Since the p-value of the ANOVA Table is lower than 0.01, there is a meaningful statistical relationship between the variables at a confidence level of $99 \%$.

In order to select the best values of temperature and time that give the better results in the prehydrolysis process, the expected values of the concentration of products in the final liquor were first established (Table 4).

Using the regression equations and the expected values, the system of equations was solved in the studied range. Table 5 presents the solutions.

Table 3: Regression equations

\begin{tabular}{|l|l|c|c|c|}
\hline & Regression Equations. & $\mathbf{R}^{2}$ & SEE $^{(\mathbf{a})}$ & AME $^{(\mathbf{b})}$ \\
\hline Xylose & Xylose $=-27.48+0.261 *$ Temp $+0.225 *$ Time & $95.05 \%$ & 1.42 & 0.92 \\
Furfural & Furfural $=-5.54+0.036^{*}$ Temp +0.01 T Time $^{2}$ & $90.89 \%$ & 0.25 & 0.18 \\
Phenols & phenol $=-4.91+0.027 *$ Temp $+0.019 *$ Time & $97.60 \%$ & 0.09 & 0.07 \\
Glucose & Glucose $=-4.78+0.041^{*}$ Temp $+0.021 *$ Time & $99.59 \%$ & 0.06 & 0.04 \\
Hemicelluloses & Hemicelluloses $=14.15-0.053 *$ Temp- $-0.023 *$ Time & $95.48 \%$ & 0.24 & 0.17 \\
\hline
\end{tabular}

${ }^{(a)}$ SSE- Standard Estimation Error, ${ }^{(b)}$ AME- Absolute Median Error

Table 4: Expected values

\begin{tabular}{|l|c|}
\hline Xylose & $\geq 35 \mathrm{~g} / \mathrm{L}$ \\
Furfural & $\leq 2.5 \mathrm{~g} / \mathrm{L}$ \\
Phenols & $\leq 1.5 \mathrm{~g} / \mathrm{L}$ \\
Hemicelluloses & $\leq 3.0 \mathrm{~g} / \mathrm{L}$ \\
\hline
\end{tabular}

Table 5: Solutions of the equations that satisfied the expected values.

\begin{tabular}{|c|c|}
\hline $\begin{array}{c}\text { Temperature } \\
\left({ }^{\circ} \mathrm{C}\right)\end{array}$ & $\begin{array}{c}\text { Time } \\
\text { (min) }\end{array}$ \\
\hline 190 & $60-63$ \\
180 & $70-82$ \\
170 & $\geq 93$ \\
\hline
\end{tabular}


The solutions show that it is possible to perform the prehydrolysis process between $180-190^{\circ} \mathrm{C}$ in times of 60-82 min, fulfilling the expected values of xylose concentration with low concentrations of furfural and phenols from lignin and a low concentration of hemicelluloses in the cellolignin residue. Below $180^{\circ} \mathrm{C}$, it is not possible to obtain the expected results in the range of variables studied.

\section{CONCLUSIONS}

The study performed on the pilot plant scale of the aqueous prehydrolysis of sugar cane bagasse using a $3^{2}$ experimental design at temperatures of $150-190^{\circ} \mathrm{C}$ and times of $60-90 \mathrm{~min}$. showed that it is possible to perform the prehydrolysis process between $180-190^{\circ} \mathrm{C}$ in times of $60-82 \mathrm{~min}$, giving concentrations of xylose $\geq 35 \mathrm{~g} / \mathrm{L}$ with concentrations of furfural $\leq 2.5 \mathrm{~g} / \mathrm{L}$ and phenols from soluble lignin $\leq 1.5 \mathrm{~g} / \mathrm{L}$ and a concentrations $\leq 3.0 \mathrm{~g} / \mathrm{L}$ of hemicelluloses in the cellolignin residue.

These parameters of temperature and prehydrolysis time could be used for the study of the later hydrolysis and fermentation stages of ethanol production from sugar cane bagasse.

\section{NOMENCLATURE}

$\begin{array}{ll}\text { UV } & \text { Ultraviolet } \\ \text { HPLC } & \begin{array}{l}\text { High performance liquid } \\ \text { chromatography }\end{array} \\ \text { Hydromodule } & \begin{array}{l}\text { represents the relationship in } \\ \text { weight between the water } \\ \text { solution and the solid phase } \\ \text { (dry bagasse). }\end{array}\end{array}$

\section{REFERENCES}

Azzam, A. M., Pretreatment of cane bagasse with alkaline hydrogen peroxide for enzymatic hydrolysis of cellulose and ethanol fermentation. J. Environ. Sci. Health, 24, (4), 421-433 (1989).

Balat, M., Balat, H. and Oz, C., Progress in bioethanol processing. Progress in Energy and Combustion Science, 34, (5), 551-573 (2008).

Bjerre, A. B., Olesen, B. and Fernqvist, T., Pretreatment of wheat straw using combined wet oxidation and alkaline hydrolysis resulting in convertible cellulose and hemicelluloses. Biotechnol. Bioeng., 49, 568-577 (1996).
Brienzo, M., Siqueira, A. F. and Milagres, A. M. F., Search for optimum conditions of sugarcane bagasse hemicelluloses extraction. Biochemical Engineering Journal 46, (2), 199-204 (2009).

Canilha, L., Carvalho, W., Almeida e Silva, J. B., Almeida Felipe, M. G. and Giulietti, M., Empirical modeling as an experimental approach to optimize the hydrolysis of sugarcane bagasse hemicelluloses with dilute $\mathrm{H}_{2} \mathrm{SO}_{4}$. Journal of Biotechnology, 136, Supp.1, S480-S481 (2008).

Cheng, K. K, Zhang, J. A., Ping, W. X., Ge, J. P., Zhou, Y. J., Ling, H. Z., Xu, J. M., Sugarcane bagasse mild alkaline/oxidative pretreatment for ethanol production by alkaline recycle process. Appl. Biochem. Biotechnol., 151, 43-50 (2008).

Claassen, P. A. M., van Lier, J. B., López Contreras, A. M., van Niel, E. W. J., Sijtsma, L., Stams, A. J. M., de Vries, S. S. and Weusthuis, R. A., Utilisation of biomass for the supply of energy carriers. Appl. Microbiol. Biotechnol., 52, 741755 (1999).

Esteghlalian, A., Hashimoto, A. G., Fenske, J. J. and Penner M. H., Modeling and optimization of the dilute sulfuric acid pretreatment of corn stover, poplar and switchgrass. Bioresour. Technol., 59, (2-3), 129-36 (1997).

Ferreira-Leitao, V., Perrone, C. P., Rodrigues, J., Franke, A. P. M., Macrelli, S., Zacchi, G., An approach to the utilization of $\mathrm{CO}_{2}$ as impregnating agent in steam pretreatment of sugar cane bagasse and leaves for ethanol production. Biotechnology for Biofuels. 3, 7, http://www.biotechnologyforbiofuels.com/conten $\mathrm{t} / 3 / 1 / 7$ (2010).

Gálvez, L. O., Cabello, A., Villamil, G., García, A., Martín, A., Costales., R., Manual de los Derivados de la Caña de Azúcar. Ed. MINAZ, Habana, Cuba, 3ra. Ed., pp. 35 (2000).

Gámez, S., Ramírez, J. A., Garrote, G., Vázquez, M., Manufacture of fermentable sugar solutions from sugar cane bagasse hydrolyzed with phosphoric acid at atmospheric pressure. J. Agric. Food Chem., 52 (13), 4172-4177, (2004).

Gámez, S., González-Cabriales, J. J., Ramírez, J. A., Garrote, G., Vázquez, M., Study of the hydrolysis of sugar cane bagasse using phosphoric acid. Journal of Food Engineering, 74, (1), 78-88 (2006).

Hahn-Hagerdal, B., Galbe, M., Gorwa-Grauslund, M. F., Liden, G., Zacchi, G., Bio-ethanol - the fuel of tomorrow from the residues of today. Trends in Biotechnology, 24, (12), 549-556 (2006).

Hernández, Y., Medina, M. and Hernández, R., Estudio preliminar de la prehidrólisis del bagazo de la caña de azúcar para la obtención de etanol. 
Proc. 14 Convención de Ingeniería y Arquitectura, 1-5 de diciembre de 2008. CD Sección FIBRATEC. ISBN 978-959-261-281-5, p. 77-80 (2008).

Jacobsen, S. E. and Wyman, C. E., Xylose monomer and oligomer yields for uncatalyzed hydrolysis of sugarcane bagasse hemicelluloses at varying solids concentration. Ind. Eng. Chem. Res., 41, 1454-1461 (2002).

Kádár, Z., Maltha, S. F., Szengyel, Z., Réczey, K., de Laat, W., Ethanol fermentation of various pretreated and hydrolyzed substrates at low initial $\mathrm{pH}$. Applied Biochemistry and Biotechnology, 84,136-140 (2007).

Klinke, H. B., Thomsen, A. B., Ahring, B. K., Inhibition of ethanol-producing yeast and bacteria by degradation products produced during pretreatment of biomass. Appl. Microbiol. Biotechnol., 66, 10-26 (2004).

Laopaiboon, P., Thani, A., Leelavatcharamas, V. and Laopaiboon, L., Acid hydrolysis of sugarcane bagasse for lactic acid production. Bioresource Technology, 101, (3), 1036-1043 (2010).

Lavarack, B. P., Griffin, G. J. and Rodman, D., The acid hydrolysis of sugarcane bagasse hemicelluloses to produce xylose, arabinose, glucose and other products. Biomass and Bioenergy, 23, (5), 367-380 (2002).

Liu, C. and Wyman C. E., The effect of flow rate of compressed hot water on xylan, lignin, and total mass removal from corn stover. Ind. Eng. Chem. Res., 42, No. 21, 5409-5416 (2003).

Laser, M, Schulman, D, Allen, S. G., Lichwa, J., Antal, Jr., M. J., Lynd, L. R., A comparison of liquid hot water and steam pretreatments of sugar cane bagasse for bioconversion to ethanol. Bioresource Technol., 81, 33-44 (2002).

Lynd, L. R, Weimer, P. J, van Zyl, W. H., Pretorious, I. S., Microbial cellulose utilization: Fundamentals and biotechnology. Microbiol. Mol. Biol. R., 66, 506-577 (2002).

Lloyd, T. and Wyman C. E., Application of a depolymerization model for predicting thermomechanical hydrolysis of hemicelluloses. Applied Biochemistry and Biotechnology, 105, (1-3), 53-67 (2003).

Mabee, W. A., Gregg, D. J., Arato, C., Berlin, A., Bura, R., Gilkes, N., Mirochnik, O., Pan, X., Kendall, P. and Saddler J. N., Updates on softwood-to-ethanol process development. Applied Biochemistry and Biotechnology, 81, 129-132 (2006).

Martín, C., Estudio de la inhibición de la fermentación de hidrolizados de bagazo de caña de azúcar para la producción de etanol. Tesis Doctoral, Facultad de Mecánica y Química, Universidad de Matanzas, Base de datos Centro Universitario, Cuba (2002).

Martínez, A., Rodríguez, M. E., York, S. W., Preston, S. F. and Ingram, L.O., Use of UV absorbance to monitor furans in dilute acid hydrolysates of biomass. Biotechnoly Progress, 16, 637-641 (2000).

Mes-Hartree, M., Dale, B. E. and Craig, W. K., Comparison of steam and ammonia pretreatment for enzymatic hydrolysis of cellulose. Appl. Microbiol. Biotechnol., 29, 462-468 (1988).

Morjanoff, P. J. and Gray, P. P., Optimization of steam explosion as method for increasing susceptibility of sugarcane bagasse to enzymatic saccharification. Biotechnol. Bioeng., 29, 733-41 (1987).

Neureiter, M., Dinner, H., Thomasser, C., Saidi, B. and Braun, R., Dilute hydrolysis of sugarcane bagasse at varying conditions. Applied Biochemistry and Biotechnology, 98-100, 49-58 (2002).

Robelo, S. C., Maciel-Filho, R., Costa, A. C., Lime pretreatment of sugarcane bagasse for bioethanol production. App. Biotechnol., 153, (1-3), 139-150 (2009).

Rodríguez-Chong, A., Ramírez, J. A., Garrote, G. and Vázquez, M., Hydrolysis of sugar cane bagasse using nitric acid: a kinetic assessment. Journal of Food Engineering 61, (2), 143-152 (2004).

Sun, Y. and Cheng, J., Hydrolysis of lignocellulosic materials for ethanol production: a review. Bioresource Technol., 83, 1-11 (2002).

TAPPI Standard Methods, Technical Association of Pulp and Paper Industries. Wood and Lignocellulosic Materials (1988).

Triana, O., Abril, A., Wong, A., Energy varieties of sugar cane as a novel source of fibre for the cellulose and paper industry. APPITA Journal 61, (5), 402-407 (2008).

Vargas, G. J. and Pereira N., Sugar cane bagasse as feedstock for second generation ethanol production. Part 1. Diluted acid pretreatment optimization. Electronic Journal of Biotechnology, 13, (3), 1-9, Issue of May 15 (2010).

Vidal, P. F. and Molinier, J., Ozonolysis of ligninimprovement of in vitro digestibility of popular sawdust. Biomass, 16, 1-17 (1988).

Wyman, C. E., Dale, B. E., Elander, R. T., Holtzapple, M., Ladisch, M. R. and Lee, Y. Y., Comparative sugar recovery data from laboratory 
scale application of leading pretreatment technologies to corn stover. Bioresour. Technol., 96, 2026-2032 (2005).

Zhui, J. Y., Wang, G. S., Pan, X. J. and Gleisner, R., The status of and key barriers in lignocellulosic ethanol production: A technological perspective. Presented as a Keynote Lecture at the International Conference on Biomass Energy Technologies, Guangzhou, China, December 3-5 (2008). 